\title{
DEVELOPMENT OF WAQF LAND PRODUCTIVITY FOR THE CONTRUCTION OF HOUSING TO LOW INCOME SOCIETY (MBR) FOR REALIZING GENERAL WELFARE
}

\section{PENGEMBANGAN PRODUKTIVITAS TANAH WAKAF UNTUK PEMBANGUNAN PERUMAHAN BAGI MASYARAKAT BERPENGHASILAN RENDAH (MBR) UNTUK MEWUJUDKAN KESEJAHTERAAN UMUM}

\author{
Saepi Syawaludin*, Martin Roestamy**, Sudiman Sihotang*** \\ saepi.syawaludin@unida.ac.id
}

(Diterima pada: 01-07-2018 dan dipublikasikan pada: 30-09-2018)

\begin{abstract}
Endowments in Indonesia have abundant potential. However, the potential of waqf has not been able to contribute to solving the problem of poverty, because the management of waqf assets in Indonesia has not been widely used productively due to the still conservative pattern of public thought. Using the Juridical-Normative method, this study tries to provide a literary explanation of the views of the Fuqhas on how the legal status of the development of the productivity of waqf property? and how is the model that can be used to develop the productivity of the waqf property? According to Al-Kamal bin Al-Hammam, the authors of the books Fathul Qadir and Al-Mirginani, the authors of the book Al-Hidayah, said that they could build buildings that were already known that the building could be useful for the ummah, and many models could be used. delivery (BGS) or build operate transfer (BOT).
\end{abstract}

Keywords: Waqf, Productivity, Build Operate Transfer (BOT)

\begin{abstract}
ABSTRAK
Harta benda wakaf di Indonesia memiliki potensi yang melimpah. Namun potensi tersebut wakaf belum dapat berkontribusi menyelesaikan persoalan kemiskinan, karena pengelolaan harta benda wakaf di Indonesia belum banyak digunakan secara produktif yang disebabkan oleh masih kolotnya pola fikir masyarakat. Dengan menggunakan metode Yuridis-Normatif kajian ini mencoba memberikan penjelasan secara literatur mengenai pandangan para Fuqha tentang bagaimana status hukum pengembangan produktivitas harta benda wakaf? serta bagaimana model yang dapat digunakan untuk pengembangan produktivitas harata benda wakaf tersebut?. Menurut Al-Kamal bin Al-Hammam pengarang kitab Fathul Qadir dan AlMirginani pengarang kitab Al-Hidayah megatakan boleh membangun bangunan yang sudah diketahui bahwa bangunan tersebut dapat bermanfaat bagi ummat, dan banyak model yang dapat digunakan salah satunya adalah dengan model perjanjian bangun guna serah (BGS) atau juga build operate transfer (BOT).
\end{abstract}

Kata Kunci : Wakaf, Produktivitas, Build Operate Transfer (BOT)

\footnotetext{
*Fakultas Hukum-Universitas Djuanda Bogor, Jl.Tol Ciawi No 1, Kotak Pos 35 Bogor 16770

** Fakultas Hukum-Universitas Djuanda Bogor, Jl.Tol Ciawi No 1, Kotak Pos 35 Bogor 16770

****Fakultas Hukum-Universitas Djuanda Bogor, Jl.Tol Ciawi No 1, Kotak Pos 35 Bogor 16770
} 


\section{A. Pendahuluan}

Cepatnya laju pertumbuhan penduduk di Indonesia mengharuskan semakin cepat juga pembangunan nasional yang dilakukan oleh Pemerintah. Hal demikian harus dilakukan karena Negara dalam hal ini Pemerintah harus memberikan kenyamanan, keamanan, serta kesejahteraan sesuai dengan apa yang diamanatkan dalam pembukaan UUD 1945 alinea ke 4 yakni melindungi segenap tumpah darah Indonesia, dan untuk memajukan kesejahteraan umum.

Berdasarkan sensus penduduk tahun 2010 , jumlah penduduk Indonesia setiap tahunnya mengalami peningkatan yang cepat. Tercatat dari hasil sensus 2010 tersebut, pada tahun 2010 jumlah penduduk sebanyak 238.5 Juta Jiwa, pada tahun 2013 jumlah penduduk sebanyak 248.8 Juta Jiwa, pada tahun 2016 jumlah penduduk sebanyak 258.7 Juta Jiwa dan pada tahun 2017 meningkat kembali menjadi 261.9 Juta Jiwa maka pertumbuhan penduduk diperkirakan 3.5 Juta Jiwa pertahunnya. ${ }^{1} \quad$ Bukan hanya pertumbuhan penduduk yang cepat, namun tingkat kemiskinan pun masih cukup terbilang tinggi. Pada September 2017 tercatat 26.58 Juta Jiwa penduduk dalam keadaan miskin. ${ }^{2}$

Apabila kita liat data di atas maka pembangunan nasional harus segera dilaksanakan oleh Pemerintah. Pembangunan tersebut bukan hanya pembangunan infrastruktur saja, tapi juga pembangunan yang melekat dengan masyarakat langsung untuk mengembangkan potensi serta kehidupan seperti pambangunan tempat tinggal. Hal tersebut perlu dilakukan mengingat masih banyaknya masyarakat

\footnotetext{
${ }^{1}$ https://databoks.katadata.co.id/datapublish/2018/01/1 2/berapa-jumlah-penduduk-indonesia. Diakses pada Kamis 22 Februari 2018

${ }^{2}$ https://www.bps.go.id/galeri diakses Kamis 22 Februari 2018
}

yang belum bahkan tidak memiliki tempat tinggal, sehingga ada dari masyarakat yang hidup dan tinggal di kandang sapi dan/atau kandang ayam sebagai tempat tidur dan tempat untuk memasak, atau segala aktifitas dilakukan hanya dalam kandang tersebut.

Salah satu unsur yang paling penting dalam melaksanakan pembangunan Nasional adalah tanah. Tanah tidak hanya tempat untuk tinggal, bermukim, berkebun, bertani, tetapi juga sebagai keperluan yang lain seperti jual beli, sewa menyewa, sebagai objek jaminan atau hal lain. Dari kegunaan tanah yang begitu penting bagi orang atau badan hukum menuntut adanya jaminan kepastian hukum atas tanah tersebut. ${ }^{3}$

Secara yuridis pengertian tanah adalah permukaan bumi atau daratan. ${ }^{4}$ Tanah merupakan sumber daya alam yang dapat dikatakan sebagai kebutuhan fundamental bagi kehidupan manusia selain tempat untuk tinggal, untuk hidup, untuk melanjutkan kehidupan sosial tanah juga dapat dimanfaatkan sebagai pemenuhan kebutuhan hidup dengan aktivitas komersial terhadapnya.

Banyaknya masjid-masjid yang bersejarah yang di bangun di atas tanah wakaf menjadi sebuah indikator atau bukti bahwa ajaran mengenai wakaf terus berkembang di bumi Nusantara. Hal ini dapat terjadi karena kedudukan wakaf dianggap ibadah tabungan artinya pahala wakaf tersebut akan terus mengalir kepada orang yang mewakafkan hartanya meskipun wakif telah meninggal dunia. ${ }^{5}$

${ }^{3}$ Urip Santoso, Hukum Agraria, Kajian Komprehensif, Kencana, Jakarta, 2012. Hlm. 64

${ }^{4}$ Boedi Harsono, Hukum Agraria Indonesia Sejarah Pembentukan Undang-Undang Pokok Agraria, Isi dan Pelaksanaanya, Djambatan, Jakarta, 2008. Hlm. 15

${ }^{5}$ Taufik Hamami, Perwakafan Tanah (Dalam Politik Hukum Agraria Nasional), Tatanusa, Jakarta, 2003. Hlm. 8 
Dalam sebuah hadits Muslim diterangkan. ${ }^{6}$

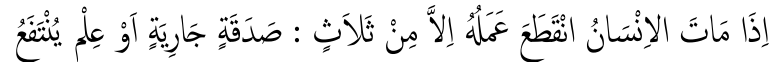

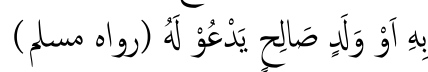

Artinya : “Apabila mati manusia terputus segala amalannya (karena ia telah mati) kecuali tiga perkara (yang akan tetap mengalir walau orang tersebut sudah meninggal) yaitu shadaqoh jariyah (termasuk juga wakaf), ilmu yang bermanfaat, dan anak yang sholeh yang senantiasa mendoakannya" (H.R Muslim)

Di Indonesia pengaturan mengenai wakaf telah diatur khusus dalam Undang-Undang No. 41 Tahun 2004 tentang Wakaf (UU Wakaf). Pengertian wakaf menurut Pasal 1 angka (1) Undang-undang ini adalah "perbuatan hukum wakif untuk memisahkan dan/atau menyerahkan sebagian harta miliknya untuk selamanya atau untuk jangka waktu tertentu sesuai dengan kepentingannya guna keperluan ibadah dan/atau kesejahteraan umum menurut syariah".

Konsideran UU Wakaf
menjelaskan bahwa langkah signifikan untuk memajukan kesejahteraan umum serta kedudukan lembaga wakaf sebagai pranata keagamaan yang bukan hanya bertujuan untuk menyediakan berbagai kepentingan ibadah dan sosial saja, namun lebih dari itu wakaf juga memiliki potensi dan manfaat ekonomi yang bila diarahkan dan dikelola dengan baik maka wakaf ini akan dapat memajukan kesejahteraan umum, maka sistem pengembangan dan pemanfaatan tanah wakaf harus terus dikembangkan yang harus tetap sesuai dengan prinsip syariah sebagai dasar konsepnya (basic concept).

Mengenai pengembangan dan pengelolaan harta benda wakaf bukan

\footnotetext{
${ }^{6}$ Sayyid Ahmad Al-Hasyimi, Mukhtarul Hadits AnNabawiyah Al-Hikam AlMuhammadiyah, Daarul 'ilmi, Surabaya, Hadits ke-127, Hlm. 16
}

hanya diperuntukkan untuk pendidikan, keagamaan, dan kesehatan saja, namun dalam Pasal 43 ayat (2) UU Wakaf juga memungkinkan pengembangan dan pengelolaan harta benda wakaf dilakukan secara produktif. Pengembangan dan pengelolaan yang dilakukan secara produktif tersebut antara lain dengan cara pengumpulan, agribisnis, investasi, produksi, penanaman modal, perdagangan, kemitraan, perindustrian, pertambangan, pembangunan gedung, apartemen, rumah susun, pengembangan teknologi, pasar swalayan, pertokoan, perkantoran, sarana pendidikan, sarana kesehatan, dan usaha-usaha lain yang tidak bertentangan dengan syariah. ${ }^{7}$

Semangat baru yang terdapat dalam Undang-Undang Wakaf dan Peraturan Pemerintah sebagai pelaksananya, menjadikan wakaf sebagai instrumen untuk menyejahterakan masyarakat muslim. Kata "menyejahterakan" dapat diartikan sebagai upaya para pihak (terutama pengelola wakaf) untuk meningkatkan kualitas hidup umat Islam melalui pendayagunaan objek wakaf. Maka itu, pendekatan yang digunakan tidak semata-mata pendekatan ekonomi, tetapi pendekatan bisnis. ${ }^{8}$

Sederhananya, bahwa wakaf di Indonesia umumnya hanya dimanfaatkan untuk kegiatan nirlaba keagamaan saja, seperti membuat masjid, mushalla, madrasah, pemakaman dan lain sebagainya. Namun ternyata Pasal 43 ayat (2) memberikan kemungkinan untuk pengembangan dan pengelolaan harta benda wakaf secara komersil artinya dari harta benda wakaf tersebut dapat menghasilkan keuntungan.

Dilihat dari web resmi Kemenag SIWAK (Sistem Informasi Wakaf) Direktorat Pemberdayaan Zakat dan

\footnotetext{
${ }^{7}$ Penjelasan Pasal 43 ayat (2) Undang-Undang Nomor 41 Tahun 2004 tentang Wakaf

${ }^{8}$ Jaih Mubarok, Wakaf Produktif, Simbiosa Rekatama Media, Bandung, 2008, Cetakan pertama, Hlm. 27.
} 
Wakaf Ditjen Bimbingan Masyarakat Kemenag RI jumlah tanah wakaf berada di 349,682 lokasi dan dengan luas tanah wakaf seluas 48,859,27 Hektar seluruh Indonesia serta penggunaan harta benda wakaf yang terdata di Kemenag antara lain yntuk musholla sebesar $28.20 \%$, untuk makam $4.59 \%$, untuk Sekolah sebesar 10.60\%, untuk Pesantren sebesar $3.22 \%$ dan untuk Sosial lainnya sebesar $8.39 \% .^{9}$

Konsep wakaf produktif pada dasarnya dilandasi oleh ketidakpuasan pihak Pemerintah (terutama Departemen Agama) terhadap pengelolaan harta wakaf yang dilakukan oleh para nazhir yang berjalan sekarang ini. Ketidakpuasan tersebut kemudian memicu pemerintah untuk memperbaikinya dengan paradigma wakaf produktif, antara lain dengan membentuk undang-undang tentang wakaf. Dengan demikian, definisi wakaf produktif secara terminologi adalah tranformasi dari pengelolaan wakaf yang alami menjadi pengelolaan wakaf yang profesional untuk meningkatkan atau menambah manfaat wakaf. ${ }^{10}$

Menurut Muhammad Syafii
Antonio Wakaf produktif adalah pemberdayaan wakaf ditandai dengan tiga ciri utama: Pertama, manajemen wakaf harus terintegrasi; dana wakaf dapat dialokasikan untuk programprogram pemberdayaan dengan segala macam biaya yang tercakup di dalamnya. Kedua, asas kesejahteraan nazhir. Pekerjaan sebagai nazhir tidak lagi diposisikan sebagai pekerja sosial, tapi sebagai profesional yang bisa hidup layak dari profesi tersebut. Ketiga, asas tranfaransi dan tanggung jawab (accountability). Badan wakaf dan lembaga yang dibantunya harus

\footnotetext{
${ }^{9}$ http://Siwak.kemenag.go.id/index_print.php diakses pada hari Senin tanggal 6 September 2018.

${ }^{10}$ Jaih Mubarok, Op. Cit. Hlm. 15
}

melaporkan proses pengelolaan dana kepada umat setiap tahun. ${ }^{11}$

Potensi tanah wakaf sangat memiliki prospek, selain dari jumlahnya yang begitu besar tanah wakaf juga banyak yang lokasinya sangat strategis, sehingga tanah wakaf tersebut dapat dikembangkan dan dikelola secara produktif. Misalnya saja dengan membangun perumahan yang dapat dijangkau oleh setiap lapisan masyarakat, termasuk masyarakat berpenghasilan rendah (MBR) yang dilakukan bisa dengan cara perjanjian sewa menyewa (kontrak), bangun-sewa (lessing), atau kerjasama pengelolaan bisnis yang nantinya hasil dari hal tersebut diatas dapat dipakai untuk keperluan ummat, seperti misalnya renovasi masjid, membantu masyarakat yang tidak mampu secara finansial, menyantuni anak yatim, janda-janda tua, atau untuk dapat menopang kegiatan seperti memberdayakan ekonomi kecil atau lemah yang ada dilingkungan sekitar. ${ }^{12}$

Kebutuhan akan rumah bagi orang perorangan atau badan, baik untuk tempat tinggal maupun untuk tempat usaha, menjadi kebutuhan yang paling mendesak untuk dipenuhi. ${ }^{13}$ Menurut Martin Roestamy rumah adalah bagian daripada unsur Negara Kesejahteraan (welfare state), karena rumah bukan hanya sebagai kebutuhan asasi, namun lebih dari itu rumah sebagai kewajiban asasi negara untuk menyediakan rumah

\footnotetext{
${ }^{11}$ Muhammad Syafii Antonio, dalam Achmad Djunaidi dan Thobieb al-Asyhar, Menuju Era Wakaf Produktif, Mumtaz Publishing, Jakarta 2007

12 Achmad Djunaidi dan Thobieb Al-Asyhar, Menuju Era Wakaf Produktif, Sebuah Upaya Progresif untuk Kesejahteraan Umat, Mitra Abadi Press, Jakarta, 2006, Hlm. 11

13 Martin Roestamy, Konsep Kepemilikan Rumah Bagi Warga Negara Asing Dalam Rangka Percepatan Peningkatan Investasi di Indonesia, Jurnal Hukum De'rechtsstaat Volume 2 No. 2 September 2016, HIm. 5
} 
untuk rakyatnya demi mewujudkan negara yang sejahtera. ${ }^{14}$

Dalam hal ini Pemerintah baik pusat atau daerah berkewajiban untuk menyelenggarakan rumah dan perumahan untuk memenuhi kebutuhan dasar manusia bagi peningkatan serta pemerataan kesejahteraan rakyat untuk menjamin hak setiap warga Negara untuk menempati, menikmati atau memiliki rumah yang layak dalam lingkungan yang sehat, aman, serasi dan teratur. ${ }^{15}$

Hal tersebut juga sejalan dengan apa yang sudah diamanatkan dalam Undang-Undang Dasar 1945 Pasal 28H ayat (1) yaitu: "Setiap orang berhak hidup sejahtera lahir dan batin, bertempat tinggal, dan mendapatkan lingkungan hidup yang baik dan sehat serta berhak memperoleh pelayanan kesehatan. Selain itu, UU Wakaf juga menyatakan dalam Pasal 5 bahwa "Wakaf berfungsi untuk mewujudkan potensi dan manfaat ekonomis harta benda wakaf untuk kepentingan ibadah dan untuk memajukan kesejahteraan umum.

Langkanya perumahan terjadi karena selain persediaan tanah yang sudah semakin sedikit bahkan hampir tidak ada menyebabkan masyarakat tidak memiliki rumah. Selain itu masih banyaknya masyarakat berpenghasilan rendah tidak mempunyai rumah disebabkan juga karena rumah yang dibangun di atas tanah biasa memiliki harga yang sangat mahal yang tidak mampu di jangkau oleh MBR.

Persepsi masyarakat, khususnya yang berpenghasilan rendah, disaat membutuhkan rumah, maka yang dicari adalah informasi mengenai perumahan yang disediakan PERUM PERUMNAS,

14 Sudiman Sihotang, Optimalisasi Hukum Perumahan Untuk Percepatan Pengadaan Rumah Untuk Masyarakat Yang Berpenghasilan Rendah (MBR), Jurnal Hukum De'rechtsstaat Volume 2 No. 1 Maret 2016, Hlm. 87

15 Indonesia, Undang-Undang Nomor 1 Tahun 2011 tentang Perumahan dan Kawasan Permukiman Lembaran Negara Tahun 2011 Nomor 7 permasalahan yang timbul saat ini adalah ketersediaan perumahan yang dikelola oleh PERUMNAS sangat terbatas, sementara kebutuhan akan rumah sangat tinggi, mengikuti tingkat pertumbuhan populasi dan daya urban yang semakin tahun semakin meningkat. ${ }^{16}$ karena hal tersebut tanah wakaf dapat dibangunkan perumahan untuk membantu kaum dhuafa memiliki rumah. Dengan begitu backlog yang terjadi di Indonesia ini dapat diselesaikan dengan pemanfaatan tanah wakaf yang yang begitu luas.

Namun dalam pengembangan harta benda wakaf ini memiliki sifat rigidas yang cukup signifikan. Rigiditas tersebut terjadi dalam keadaan dimana wakaf sebagai pranata keagamaan diatur secara khusus juga mengenai syaratsyarat seorang dapat berwakaf, rukun wakaf, serta mengatur mengenai harta wakaf tersebut hanya boleh digunakan atau diperuntukkan untuk apa saja, dan disalurkan manfaatnya kepada siapa saja, kemudian harta wakaf bolehkah digunakan selain daripada atau keluar dari peruntukkannya.

Karena hal tersebut masih banyak masyarakat di Indonesia khususnya, memiliki paradigma bahwa harta benda wakaf hanya boleh digunakan untuk nirlaba keagamaan saja seperti membangun Masjid, untuk Pondok Pesantren, Majlis Ta'lim, dan sosial lainya. Sedangkan dalam Pemerintah melalui peraturan Perundang-undangan jelasnya Undang-undang No. 4 Tahun 2004 tentang Wakaf dalam Pasal 43 ayat (2) mengatur paradigma baru mengenai pengelolaan wakaf dimana menurut Pasal ini wakaf dapat dikelola dan dikembangkan secara produktif seperti untuk pertambangan, perkantoran, pasar swalayan,

${ }^{16}$ R. Yuniar Anisa Ilyanawati dkk, Konsolidasi Tanah Perkotaan Terhadap Pembangunan Perumahan Bagi masyarakat Berpenghasilan Rendah (MBR) di Kota Bogor dan Kota Depok, Jurnal Living Law ISSN 2087-4936 Volume 9 Nomor 1, Januari 2017, Hlm. 10 
perhotelan, rumah sakit dan lain sebagainya. Hal ini menjadi tantangan tersendiri untuk Indonesia dimana Pemerintah harus memberikan penjelasan serta pemahaman kepada masyarakat yang masih memiliki pola pikir kolot, sehingga dengan begitu usaha mengembangkan harta benda wakaf secara produktif akan lebih mudah dilakukan.

Berdasarkan uraian diatas Penulis tertarik untuk mengkaji mengenai perkembangan produktivitas tanah wakaf untuk pembangunan perumahan bagi masyarakat berpenghasilan rendah (MBR) dalam mewujudkan kesejahteraan umum yang dikaji mengenai bagaimana status hukum dan bagaimana model dalam mengenbangkan produktivitas tanah wakaf tersebut.

\section{B. Status Hukum Pengembangan Produktivitas Tanah Wakaf Untuk Pembangunan Perumahan Dalam Mewujudkan Kesejahteraan Umum}

Wakaf merupakan sebuah 'amaliah (perbuatan) yang dalam agama Islam disyariatkan. Dewasa ini, Indonesia sedang menggalakkan berbagai program-program strategis dalam rangka mengoptimalkan potensi tanah wakaf yang begitu besar tersebut. Dalam buletin Swara Cinta tercatat hampir 4,4 miliar $\mathrm{m}^{2}$ yang tersebar di sekitar 366.595 lokasi merupakan harta wakaf terbesar di dunia. ${ }^{17}$

Meski potensi wakaf yang begitu besar namun dalam pengelolaan dan pengembangannya masih sangat sedikit sekali digunakan secara produktif. Menurut Bapak Sigit bagian divisi pengelolaan dan pengembangan wakaf Badan Wakaf Indonesia, sekitar 10\% dari keseluruhan asset wakaf pada saat ini yang dikelola secara produktif. ${ }^{18}$

$$
\text { Mayoritas masyarakat di }
$$

Indonesia masih menganggap bahwa wakaf sebagai pranata keagamaan hanya dapat digunakan untuk sarana-sarana nirlaba religius saja, artinya tanah wakaf itu hanya boleh dikelola untuk membangun masjid, membangun sekolah, membangun majlis ta'lim, membangun pesantren dan digunakan untuk pemakaman. Sehingga banyak dari wakif mewakafkan tanahnya dengan ikrar boleh digunakan hanya terbatas kepada hal-hal tersebut saja. Apabila pengembangan tanah wakaf tersebut digunakan untuk membangun properti seperti gedung-gedung perkantoran, rumah toko (ruko), rumah sakit, perumahan masih dianggap hal yang keluar aturan dari hakikat wakaf.

Dalam sebuah hadits yang mashur yang menceritakan tentang wakaf Umar bin Khattab yang diriwayatkan oleh Imam Bukhari dan Muslim serta temantemannya dalam kitab "As-Sunan" : Dari Umar bin Khattab r.a, ia berkata: "saya mendapatkan tanah di Khaibar. Kemudian saya mendatangi Rasulullah SAW, maka saya katakan kepadanya, "saya mendapatkan tanah, dan sebelumnya saya tidak pernah mendapatkan sesuatu yang lebih saya sukai dan lebih berharga dari tanah itu, maka apa yang bisa engkau perintahkan kepada saya? Beliau bersabda "Apabila kamu mau, kamu bisa mewakafkan pokonnya dan menyedekahkannya". Maka Umar pun mewakafkan tanah itu, tidak untuk dijual atau diberikan, melainkan hasilnya dibagikan kepada fakir miskin, kerabat, para tamu dan orang-orang yang dalam perjalanan. Tidak berdosa bagi yang mengelolanya untuk memakan darinya dengan cara
17 Swara Cinta, Wakaf dan Kesejahteraan Umat, Edisi 81 Tahun VII/NOV-DES 2017, penerbit PT Digdaya Dinamika Publika, Jakarta 2017, Hlm. 10
18 Berdasarkan hasil interview (wawancara) yang dilakukan pada hasi Selasa tanggal 17 April 2018 di kantor Badan Wakaf Indonesia, Gd. Al-Bayt AlQuran, TMII, Jakarta 
yang baik, bukan untuk memupuk harta dan memberi makan. ${ }^{19}$

Hadits tersebut dapat dikatakan menjadi dasar dalam praktek perwakafan karena dengan jelas Rasulullah memerintahkan Umar bin Khattab untuk mewakafkan tanahnya. Maka jika kita amati betul hadits tersebut diatas, pemahaman tentang wakaf produktif dapat kita temukan dari sabda Rasul "menyedekahkannya". Artinya bahwa hakikat dari wakaf adalah agar masyarakat dapat merasakan manfaatnya bahkan dapat membantu meningkatkan kesejahteraan umat. Selain dari pada itu dari hadits tersebut juga dapat kita temukan bahwa pengelola (Nazhir) boleh mengambil manfaat dari wakaf tersebut, yang dalam peraturan perundang-undangan di Indonesia Nazhir berhak mendapatkan $10 \%$ dari hasil atau manfaat wakaf yang dikelolanya.

Namun kemudian zaman semakin berkembang dan dari perkembangan zaman tersebut pula pemahaman mengenai wakaf ikut berkembang. Pemahaman perkembangan pengelolaan wakaf tersebut terbukti dengan mulai banyaknya tanah wakaf yang dikembangkan kepada hal produktif yang memiliki nilai ekonomis yang dapat meningkatkan kesejahteraan umat.

Mengenai dikembangkannya secara produktif yakni seperti membangun rumah sakit, rumah toko (ruko), perumahan diatas tanah wakaf masih diperdebatkan mengenai status hukumnya boleh atau tidak. Sebenarnya tidak banyak perdebatan diantara para ahli fiqh mengenai tidak diperbolehkannya mengembangkan tanah wakaf untuk membangun berbagai properti diatasnya, namun yang banyak dibahas adalah bahwa dengan dikembangkannya tanah wakaf tersebut dalam bentuk pembangunan properti tidak lantas membuat tanah wakaf

${ }^{19}$ Mundzir Qahaf, An-Nushush Al-Iqtishadiyah, Nash No. 793 tersebut berubah (rusak) dari ciri-ciri ketika diwakafkan.

Latar belakang adanya paradigma baru mengenai pengembangan tanah wakaf produktif adalah karena banyaknya tanah wakaf yang tidak terurus bahkan rusak, maka karena pemandangan tersebut menurut AlKharsy (1101) pengarang kitab Syarh Mukhtashar Khalil, wali wakaf (Nazhir) dapat menyewakan atau kerjasama dengan pihak ketiga untuk menjaga tanah atau barang wakaf agar tidak rusak sedangkan untuk perbaikannya tidak ada. ${ }^{20}$ Sehingga karena tidak ada biaya dalam mengelola dan mengembangkannya maka dapat melakukan mitra atau kerjasama dengan pihak penyewa atau pihak ketiga.

Lebih jauh menurut Al-Kamal bin Al-Hammam pengarang kitab Fathul Qadir dan Al-Mirginani pengarang kitab Al-Hidayah mengatakan boleh membangun bangunan yang sudah diketahui bisa dimanfaatkan oleh orangorang yang berhak (umat). Kemudian mereka mengatakan selama bangunan tersebut berada diatas tanah wakaf maka dapat diambil manfaatnya, dan selama tanah wakafnya tidak berubah seperti ketika pertama diwakafkan. Serta hasilnya berhak untuk dipergunakan oleh orang-orang yang berhak ${ }^{21}$ yakni masyarakat atau umat yang memang berhak atau apabila tanah wakaf tersebut sudah disebutkan oleh wakif untuk hasilnya hanya dapat disalurkan kepada kelompok atau kalangan tertentu maka merekalah yang berhak mendapatkannya.

Turki adalah salah satu negara yang mempunyai sejarah perwakafan yang sangat menarik. Sejak masa Turki Utsmani, wakaf telah menghidupi berbagai pelayanan publik dan menopang pembiayaan berbagai

20 Munzdir Qahaf, Manajemen Wakaf Produktif, Penerjemah Muhyidin Mas, Khalifa (Pustaka AlKautsar Group), Jakarta, 2008, Hlm. 88

${ }^{21}$ Ibid. Hlm. 86-87 
bangunan seni dan budaya. ${ }^{22}$ Adapun wakaf yang dikelola secara produktif di Turki antara lain: masjid, asrama mahasiswa, rumah untuk usaha, hotel dan caravan, toko, rumah atau apartemen, depahs and tables, dan properti lainnya. ${ }^{23}$

Bukannya hanya di Turki, pengembangan tanah wakaf produktif juga dilakukan di Arab Saudi. Pemerintah Saudi mengelola kebun wakaf Utsman dengan baik, setiap keuntungan yang didapat dari hasil panen dibagi dua yakni untuk dibagikan kepada anak yatim dan fakir miskin lalu separuhnya lagi disimpan di sebuah bank dengan rekening atas nama Utsman bin Affan. ${ }^{24}$

Rekening tersebut dipegang oleh Kementrian Wakaf, dan uang tersebut dipakai untuk membeli tanah di kawasan Markaziyah (area eksklusif) dekat masjid Nabawi. Kemudian diatas tanah itu dibangun hotel, dan hotel tersebut kini dikelola oleh Sheraton berdiri gagah dengan 15 lantai dan setiap lantainya terdiri dari 24 kamar, selain itu di hotel tersebut juga dilengkapi dengan restoran besar dan tempat belanja. ${ }^{25}$

\section{Model Pengembangan Produktivitas Tanah Wakaf Untuk Pembangunan Perumahan Dalam Mewujudkan Kesejahteraan Umum}

Tanah wakaf adalah tanah yang tujuan sebenarnya adalah untuk kegiatan sosial, artinya tanah wakaf diharuskan digunakan sebaik mungkin agar dapat menghasilkan manfaat yang sebesarbesarnya bagi masyarakat yang memang berhak untuk mendapatkan manfaat dari

\footnotetext{
22 Uswatun Hasanah dalam buku Suhrawardi K. Lubis, dkk, Wakaf dan Pemberdayaan Umat, Edisi 1, Cetakan 1, Sinar Grafika, Jakarta, 2010, Hlm. 23

${ }^{23} \mathrm{Ibid}$, Hlm. 26

${ }^{24}$ Swara Cinta, Op. Cit. Hlm. 14-15

25 Ibid. Hlm. 15
}

apa yang dihasilkan dari harta benda wakaf tersebut.

Namun dewasa ini manfaat tanah wakaf kurang dapat dirasakan secara maksimal oleh masyarakat karena pengelolaan tanah wakaf di Indonesia saat ini tidak baik, dengan kata lain pengelolaan tanah wakaf tersebut tidak dilakukan secara produktif, sehingga tanah wakaf yang begitu besar dan berada di ratusan lokasi tidak banyak memberikan manfaat kepada masyarakat.

Banyak dari terhambatnya pengembangan secara produktif tersebut adalah wakif menyebutkan atau menentukan peruntukkan wakaf dalam akta ikrar wakaf (AIW) hanya untuk satu peruntukkan saja. Oleh karena hal demikian, langkah awal agar tanah wakaf dapat dikembangkan secara produktif, perlu ditambahkan klausul yang lain dalam AIW yang menyebutkan bahwa tanah wakaf boleh digunakan kepada peruntukan yang lain selain daripada peruntukan utama yang telah ditentukan dalam rangka meningkatkan kesejahteraan umum.

Namun Pasal 40 UU Wakaf mengingatkan atau membatasi bahwa tanah wakaf boleh dikembangkan secara produktif, tetapi tanah wakaf tidak boleh dijadikan jaminan, disita, dihibahkan, dijual, diwariskan, ditukar, dan/atau dialihkan dalam bentuk pengalihan lain mengharuskan kehati-hatian dalam mengelola harta benda wakaf terlebih jika ingin dikembangkan untuk wakaf produktif.

Di Indonesia backlog (kesenjangan) antara perkembangan penduduk dan persediaan rumah yang layak huni menjadi fenomena yang tidak dapat dihindari saat ini. Hal tersebut terjadi bukan karena Pemerintah tidak memiliki program membangun rumah layak huni bagi masyarakat, melainkan hal tersebut disebabkan karena anggaran untuk program pengadaan perumahan dari APBN sangat kecil dan persediaan 
tanah (land bank) yang tidak lagi banyak tersedia. Maka berangkat dari hal tersebut, Pemerintah (Kemenpera) mulai melirik tanah wakaf sebagai alternatif atau solusi untuk dapat menyelesaikan persoalan backlog (kesenjangan) perumahan tersebut.

Dalam konteks wakaf, pembiayaan proyek wakaf bertujuan untuk mengoptimalkan fungsi harta wakaf sebagai penunjang atau prasarana dalam meningkatkan kualitas hidup dan kehidupan sumber daya insani. ${ }^{26}$ hal ini dapat dikatakan sesuai atau sejalan dengan apa yang menjadi tujuau, syarat, dan fungsi dari wakaf tersebut, yakni untuk meningkatan kesejahteraan umum.

Tanah wakaf adalah tanah yang memiliki keunikan secara tersendiri yang tidak dimiliki oleh tanah biasa. Cara perlakuan dalam mengelola dan mengembangkan tanah wakaf dan tanah biasa cukup berbeda, pada suatu keadaan tanah wakaf dapat diperlakukan sama seperti tanah biasa dan pada keadaan lain tanah wakaf diperlakukan beda seperti tanah biasa. Oleh karenanya dengan adanya keadaan tersebut maka dalam mengembangkan tanah wakaf untuk tujuan produktif, tujuan bisnis atau untuk tujuan yang lain perlu adanya model yang dianggap sesuai dan tepat dalam mengembangkan tanah wakaf tersebut.

Pengelola wakaf (Nazhir) boleh pemegang hak eksklusif terhadap pengelolaan wakaf kepada beberapa model pembiayaan, seperti Murabahah, istisna, ijarah, dan mudharabah. Sebagai tambahan ada juga yang disebut berbagi kepemilikan atau syari'atul milk, yakni ada beberapa kontraktor yang berbagi manajemen atau menugaskan manajemen proyek pada pihak penyedia pembiayaan atau disebut dengan model bagi hasil (out put

26 Direktorat Jenderal Bimbingan Masyarakat Islam dan Penyelenggaraan Haji, Pedoman Pengelolaan dan Pengembangan Wakaf, 2003, Hlm. 97 sharing). Diatara model-model tersebut adalah sebagai berikut: ${ }^{27}$

1. Model Pembiayaan Murabahah. Pada model ini mengharuskan pengelola (nadzir) harta wakaf mengambil fungsi sebagai pengusaha (enterprenueur). Nadzir membuat kontrak murabahah dengan bank islami. Sehingga pembiayaan datang dari bank Islami dan nadzir menjadi pengendali proses investasi dengan membeli peralatan dan material yang dibutuhkan untuk membangun atau memproduktifkan harta wakaf tersebut. Oleh karenanya nadzir menjadi penghutang (debitor) kepada lembaga perbankan yakni mengenai pembelian peralatan dan material ditambah dengan mark up pembiayaan, dan hutang tersebut akan dibayarkan dari hasil pendapatan harta wakaf.

2. Model istisna adalah transaksi jual beli dalam bentuk pemesanan pembuatan barang dengan spesifikasi dan kriteria tertentu yang telah disepakati dengan pembayaran sesuai dengan kesepakatan. Model ini memungkinkan pemberian wewenang kepada pengelola harta wakaf untuk menjalin mitra dan membuat kontrak perjanjian dengan bentuk istisna. Pengelola wakaf memesan pengembangan pembiayaan kepada lembaga pembiayaan (Bank Syari'ah) dan lembaga pembiayaan tersebut membuat kontrak dengan kontraktor untuk memenuhi pesanan pengelola wakaf atas nama lembaga pembiayaan. ${ }^{28}$ resolusi Islamic Fiqh Academi dari OKI berpendapat bahwa istisna sesuai dengan kontrak syari'ah dimana pembayaran dapat dilakukan dengan cara penangguhan atas dasar kesepakatan para pihak.

\footnotetext{
${ }^{27}$ Kementrian Agama republik Indonesia, Strategi Kemitraan Nazhir. . Op. Cit. Hlm. 59-67

${ }_{28}$ Muhammad Syafi'i Antonio, Bank Syari'ah dari Teori ke Praktek, GIP, Jakarta. Hlm. 113
} 
3. Model Ijarah adalah model yang penerapannya adalah dimana pengelola harta wakaf tetap memegang kendali penuh terhadap manajemen proyek. Implementasi model ini adalah pengelola harta wakaf memberikan izin kepada lembaga pembiayaan (financer) untuk mendirikan bangunan atau gedung diatas tanah wakaf. Bangunan dan gedung yang di bangun diatas tanah wakaf tersebut milik Financer, namun yang mengendalikan manajemen adalah pengelola harta wakaf, pengelola harta wakaf memasarkan atau menyewakan bangunan atau gedung tersebut untuk jangka waktu yang disepakati oleh pihak pengelola harta wakaf dan lembaga pembiayaan. Pengelola wakaf membayar secara berkala (periodik) kepada lembaga pembiayaan dari hasil sewa bangunan dan gedung tersebut untuk mengembalikan modal pokok dan keuntungan yang telah disepakati, sehingga penyedia dana akan kembali modalnya dan sekaligus mendapat keuntungan sesuai yang disepakati, dan setelah kontrak habis maka harta wakaf itu kembali kepada pengelola harta wakaf sepenuhnya dan lembaga penyedia dana tidak lagi boleh masuk dalam harta wakaf tersebut.

4. Model Mudharabah. Pada model mudharabah ini pengelola harta wakaf sama posisinya dengan modal pembiayaan murabahah yakni pengelola wakaf memposisikan dirinya sebagai pengusaha (mudharib) dan mengenai pembiayaan dilikuiditas dari lembaga pembiayaan. Dana pembiayaan tersebut dapat digunakan misalnya untuk membangun gedung seperti perumahan, apartemen, dan hotel diatas tanah wakaf. Pengelola harta wakaf secara eksklusif memegang peranan dalam memanajemen harta wakaf. Kemudian hasil dari pendapatan harta wakaf tersebut dibagi dengan tingkat bagi hasil yang disepakati sedemikian rupa sehinga menutup biaya usaha untuk manajemen sebagaimana penggunaan tanahnya. Perbedaan yang dapat dilihat dari model murabahah dan model mudharabah ini adalah jika murabahah dana pembiayaan dianggap sebagai hutang dan pengelola dianggap sebagai penghutang (debitor) sehingga pengelola diharuskan untuk membayar kepada lembaga pembiayaan secara periodik. Sedangkan mudharabah adalah pengelola dan lembaga pembiayaan bekerja sama dan hasil dari harta wakaf tersebut dibagi sesuai dengan apa yang sudah disepakati.

5. Model pembiayaan berbagi kepemilikan. Model ini dapat dipergunakan apabila kedua belah pihak secara pribadi dan bebas memiliki benda yang saling berkaitan satu sama lain. Bentuk pelaksanaan dari model ini misalnya pengelola wakaf mengijinkan lembaga pembiayaan membangun gedung atau membangun perumahan dan keduanya bersepakat untuk berbagi hasil yang diperoleh diantara keduanya. Menurut fikh Syarikat AlMulk kedua belah pihak bertanggung jawab atas barangnya masingmasing. pada model ini juga, pengelola harta wakaf dan lembaga pembiayaan bersepakat membagi tugas untuk memanajemen atau bisa juga menugaskan kepada pihak lain, dan pihak yang memanajeman (mengelola) diberikan tambahan prosentase sebagai kompensasi dari usahanya (memanajemen). Tambahan tersebut ditetapkan dalam jumlah uang tertentu atau proporsi hasil (output). Serta apabila salah satu pihak hendak megundurkan diri maka para pihak dapat menyetujui penjualan penyedia dana pada wakaf dan menggunakan hasil dari harta 
wakaf tersebut sebagai pembayaran untuk harga barangnya.

6. Model pembiayaan wakaf dengan Build-Operate-Transfer (BOT). Pembiayaan dengan sistem BOT adalah nadzir menjalin kontrak dengan sponsor (investor). Dalam model ini investor selain daripada membiayai juga dapat mendesain, membangun, mengoperasikan dan mengelola seluruh fasilitas dari proyek tersebut hingga waktu yang telah disepakati. Dalam bahasa yang lebih lugas, BOT adalah kemitraan antara nadzir-investor dengan pola kerja bangun, kelola, alih milik. Selama waktu yang ditentukan investor berhak mendapatkan penghasilan dari pengoperasian proyek tersebut untuk dapat mengembalikan modal dan mendapatan laba (keuntungan), setelah waktu yang ditentukan berakhir maka kepemilikan sepenuhnya kembali kepada nadzir tanpa biaya apapun.

Pihak-pihak yang dapat berpartisipasi dalam model BOT ini adalah granting authority (pemberi otoritas), misalnya sponsor proyek, satu atau lebih instansi finansial. Granting authority berperan untuk mengidentifikasi keperluan dan persyaratan proyek, menetapkan periode konsesi, mencari penawar atau lelang, dan menyerahkan kontrak. Sponsor proyek dapat sebagai individu, perusahaan, join ventur, konsorsium (gabungan pengusaha) yang telah berpengalaman dalam melaksanakan pembangunan proyek. Mengenai pembagian hak dan kewajiban, pembagian hasil, pemutusan kontrak dan penyelesaian masalah-masalah dituangkan dalam sebuah perjanjian.

Maka berdasarkan model-model di atas yang dapat digunakan untuk pengembangan tanah wakaf produktif, model pengembangan pembangunan perumahan di atas tanah wakaf dengan sistem BOT dapat menjadi pilihan model bagi para Nazhir atau lembaga wakaf untuk dapat lebih memproduktifkan tanah wakaf sehingga dapat mewujudkan apa yang menjadi tujuan, fungsi wakaf yakni mewujudkan kesejahteraan umum.

Model pengembangan tanah wakaf dengan sistem BOT dirasa memiliki banyak kelebihan dan keuntungan meski di lain sisi juga memiliki beberapa kerugian. Namun kerugian tersebut sebenarnya dapat diminimalisir kemungkinannya dengan cara Nazhir yang akan menggunakan model ini mengetahui dan paham betul mengenai pola Model BOT ini. Dengan begitu, Nazhir telah mengetahui apa dan bagaimana pola BOT ini berjalan dan oleh karena Nazhir dapat mengantisipasi setiap kemungkinan yang dapat merugikan dengan menuangkannya dalam perjanjian dengan pihak swasta atau pihak ketiga tersebut.

Karena perumahan tersebut dibangun di atas tanah wakaf, maka sebaiknya dalam perjanjian juga dituangkan mengenai status kepemilikan atau penguasaan rumah oleh calon penghuni rumah tersebut. Misalnya dalam perjanjian dituangkan ketika rumah sudah selesai di bangun, maka status penguasaan setiap unit rumah tersebut bukan di jual kepada calon penghuni rumah melainkan dengan sistem sewa. Penghuni rumah tersebut boleh menyewa dengan jangka waktu yang cukup lama dengan juga membayar sewa tersebut sekaligus sesuai dengan yang diinginkan, atau menyewa hanya untuk jangka waktu secara periodik seperti satu bulan atau satu tahun saja. Misalnya saja waktu konsesi pengembangan tersebut selama 20 sampai 30 tahun, maka MBR dapat menyewa selama konsesi tesebut berlangsung dan sewa tersebut dapat di perpanjang sesuai dengan keinginan MBR, dengan begitu MBR dapat mengusai rumah tersebut seperti rumahnya sendiri meskipun terikat 
beberapa syarat dan ketentuan yang disepakati. Kemudian untuk pembayaran sewa tersebut dibayarkan kepada pihak ketiga sampai jangka waktu yang telah disepakati atau dibagi sesuai persentase yang telah disepakati dengan pengelola tanah wakaf tersebut. Misalnya Developer menghabiskan sebesar Rp. 3000.000.000.000,- (tiga triliun rupiah), maka developer dapat menentukan harga sewa rumah tersebut per-bulan, per-tahun bahkan selama berpuluh-puluh tahun, dan penentuan harga tersebut sudah termasuk kepada penghitungan keuntungan yang akan didapat oleh Developer secara proporsional. Selain itu, jika pada kesepakatan di atas pembayaran sewa dibayarkan kepada pihak ketiga selama konsesi, maka pihak pengelola tanah wakaf berhak mendapatkan retribusi dari pihak ketiga pertahunnya.

Lazimnya jangka waktu BOT menurut Pasal 229 ayat (1) Peraturan Menteri Dalam Negeri No. 19 Tahun 2016 tentang Pedoman Pengelolaan Barang Milik Daerah BOT dapat dilakukan paling lama 30 (tiga puluh) tahun sejak ditandataganinya perjanjian. Namun hal tersebut tidak menjadi mutlak karena jangka waktu konsesi dapat dilakukan sesuai kesepakatan para pihak. Setelah jangka waktu perjanjian BOT dengan pihak ketiga sudah selesai, pihak ketiga menyerahkan bangunan perumahan tersebut kepada pengelola wakaf sepenuhnya dan biasanya tanpa syarat, dan ketika pihak ketiga menyerahkan bangunan tersebut maka pada saat itu juga penguasaan untuk mengoperasikan bangunan tersebut menjadi kewenanga penuh pengelola wakaf dan pihak ketiga tidak lagi boleh ikut terlibat pada setiap pengelolaan bangunan tersebut.

Keuntungan yang dapat dirasakan dari model BOT ini adalah pengelola wakaf yang ingin mengembangkan wakafnya menjadi lebih produktif maka dengan model BOT pengelola wakaf tidak perlu mengeluarkan biaya karena biaya ditanggung oleh pihak ketiga, pengembangan tanah wakaf menjadi cepat, mendapatkan bangunan secara utuh ketika konsesi sudah selesai, sistem manajemen atau administrasi sudah baik karena sudah tersistematis dari pihak ketiga, promosi pada perumahan tersebut sudah baik dimata publik karena telah dipromosikan lebih awal oleh pihak ketiga, beban menanggung resiko yang relatif kecil, dapat membantu masyarakat berpenghasilan rendah karena disediakan perumahan yang harganya masih terjangkau, dapat menjadi solusi untuk proyek yang memakan biaya banyak dan sulit dilakukan, serta menyerahkan sementara pengoprasian tanah wakaf kepada pihak ketiga atau investor tanah wakaf tersebut akan lebih berkembang sehingga memberikan harapan yang lebih baik dalam peningkatan kesejahteraan umum dan juga dari tanah wakaf tersebut dapat bersaing dalam lingkup pasar ekonomi kreatif. Kemudian bagi pihak ketiga atau investor akan memiliki keuntungan karena diberi kesempatan untuk memasuki bidang yang memang belum lumrah dilakukan oleh pihak lain.

Namun demikian menggunakan model BOT juga memiliki kerugian yang mungkin saja terjadi, seperti untuk pengelola wakaf maka dengan model BOT ini berarti menyerahkan pengoprasian lahan strategis tanah wakaf kepada pihak ketiga selama konsesi berlangsung, dan pihak ketiga atau investor akan mengawasi setiap fasilitas yang masih dalam penguasaannya selama konsesi.

\section{Kesimpulan}

Sebagaimana uraian serta pembahasan diatas maka kesimpulan yang dapat Penulis ambil dari penelitian ini adalah sebagai berikut:

1. Status hukum pengembangan produktivitas tanah wakaf untuk pembangunan perumahan dapat dikatakan statusnya adalah boleh 
(Jaiz). Bolehnya mengembangkan produktivitas tanah wakaf untuk membangun perumahan tersebut karena masih sejalan dengan syariat, tujuan dan fungsi serta peruntukkan wakaf yang diatur dalam UU Wakaf Pasal 22 huruf c, d, dan e, yakni; c) bantuan kepada fakir miskin, anak terlantar, yatim piatu, dan beasiswa; d) kemajuan dan peningkatan ekonomi umat; dan e) untuk kemajuan kesejahteraan umum lainnya yang tidak bertentangan dengan syariah dan peraturan perundang-undangan. Status boleh itu juga dikuatkan kembali dalam Pasal 43 ayat (2) UU Wakaf yang menyatakan bahwa pengelolaan dan pegembangan harta wakaf dilakukan secara produktif yang dalam penjelasan Pasal 43 ayat (2) produktivitas itu dapat berupa investasi, penanaman modal, produksi, pertambangan, perkantoran, pasar swalayan, pembangunan gedung, apartemen, rumah susun dan diakhir ditutup dengan usaha-usaha lain yang tidak bertentangan dengan syariah. Selain daripada itu para ahli fiqih seperti AlKamal bin Al-Hammam pengarang kitab Fathul Qadir dan Al-Mirginani pengarang kitab Al-Hidayah berpendapat boleh membangun bangunan yang sudah diketahui bisa dimanfaatkan oleh orang-orang yang berhak (umat), bermakna bahwa tanah wakaf dapat dikelola dan dikembangkan secara produktif yang dalam hal boleh di bangun perumahan di atas tanah wakaf dengan syarat tidak lekas merusak atau menghilangkan status wakaf tersebut.

2. Model pengembangan produktivitas tanah wakaf untuk pembangunan perumahan dapat dilakukan dengan beberapa model. Seperti model murabahah, mudharabah, istisna, ijarah, syari'atul milk (berbagi kepemilikan), menciptakan wakaf baru dan model BOT (built, operate, transfer). Model yang digunakan harus sesuai, mengingat wakaf memiliki sifat yang khusus dalam memperlakukannya. Model pengembangan tanah wakaf untuk lebih produktif dapat melibatkan pihak ketiga baik dari instansi Pemerintahan atau swasta. Nazhir dapat bekerjasama dengan pihak ketiga untuk membangun gedungdedung atau perumahan sehingga dalam rangka melaksanakan paradigma baru mengenai wakaf yakni menjadikan pengelolaan dan pengembangan wakaf menjadi lebih produktif itu dapat terealisasi yang nantinya diharapkan berimplikasi dalam mewujudkan kesejahteraan perokonomian ummat. Oleh karena itu, salah satu alternatif model yang dapat digunakan adalah dengan menggunakan model BOT. Dengan model BOT pengelola wakaf tidak harus mengeluarkan biaya untuk membangun perumahan tersebut, karena semua pembiayaan untuk membangun perumahan tersebut ditanggung oleh pihak ketiga atau investor.

\section{A. Buku-buku}

\section{DAFTAR PUSTAKA}

Achmad Djunaidi dan Thobieb Al-Asyhar, Menuju Era Wakaf Produktif, Sebuah Upaya Progresif untuk Kesejahteraan Umat, Mitra Abadi Press, Jakarta, 2006.

Boedi Harsono, Hukum Agraria Indonesia Sejarah Pembentukan Undang-Undang Pokok Agraria, Isi dan Pelaksanaanya, Djambatan, Jakarta, 2008. 
Direktorat Jenderal Bimbingan Masyarakat Islam dan Penyelenggaraan Haji, Pedoman Pengelolaan dan Pengembangan Wakaf, 2003.

Muhammad Syafii Antonio, dalam Achmad Djunaidi dan Thobieb al-Asyhar, Menuju Era Wakaf Produktif, Mumtaz Publishing, Jakarta 2007 , Bank Syari'ah dari Teori ke Praktek, GIP, Jakarta.

Munzdir Qahaf, Manajemen Wakaf Produktif, Penerjemah Muhyidin Mas, Khalifa (Pustaka Al-Kautsar Group), Jakarta, 2008. , An-Nushush Al-Iqtishadiyah, Nash No. 793

Sayyid Ahmad Al-Hasyimi, Mukhtarul Hadits An-Nabawiyah Al-Hikam AlMuhammadiyah, Daarul 'ilmi, Surabaya, Hadits ke-127.

Taufik Hamami, Perwakafan Tanah (Dalam Politik Hukum Agraria Nasional), Tatanusa, Jakarta, 2003.

Urip Santoso, Hukum Agraria, Kajian Komprehensif, Kencana, Jakarta, 2012.

Uswatun Hasanah dalam buku Suhrawardi K. Lubis, dkk, Wakaf dan Pemberdayaan Umat, Edisi 1, Cetakan 1, Sinar Grafika, Jakarta, 2010.

\section{B. Karya Ilmiah / Jurnal}

Martin Roestamy, Konsep Kepemilikan Rumah Bagi Warga Negara Asing Dalam Rangka Percepatan Peningkatan Investasi di Indonesia, Jurnal Hukum De'rechtsstaat Volume 2 No. 2 September 2016.

R. Yuniar Anisa Ilyanawati dkk, Konsolidasi Tanah Perkotaan Terhadap Pembangunan Perumahan Bagi masyarakat Berpenghasilan Rendah (MBR) di Kota Bogor dan Kota Depok, Jurnal Living Law ISSN 2087-4936 Volume 9 Nomor 1, Januari 2017.

Sudiman Sihotang, Optimalisasi Hukum Perumahan Untuk Percepatan Pengadaan Rumah Untuk Masyarakat Yang Berpenghasilan Rendah (MBR), Jurnal Hukum De'rechtsstaat Volume 2 No. 1 Maret 2016.

Swara Cinta, Wakaf dan Kesejahteraan Umat, Edisi 81 Tahun VII/NOV-DES 2017, penerbit PT Digdaya Dinamika Publika, Jakarta 2017.

\section{Undang-Undang}

Undang-Undang Nomor 4 Tahun 2004 tentang Wakaf

Undang-Undang Nomor 1 Tahun 2011 tentang Perumahan dan Kawasan Permukiman

\section{Dokumen Lainnya}

https://databoks.katadata.co.id/datapublish/2018/01/12/berapa-jumlah-pendudukindonesia. Diakses pada Kamis 22 Februari 2018

https://www.bps.go.id/galeri diakses Kamis 22 Februari 2018

http://Siwak.kemenag.go.id/index_print.php diakses pada hari Senin tanggal 6 September 2018 